Jurnal Gizi dan Dietetik Indonesia

Vol. 5, No. 1, 2017: 31-43
Tersedia online pada: http://ejournal.almaata.ac.id/index.php/IJND DOI : http://dx.doi.org/10.21927/ijnd.2017.5(1).31-43

\title{
Status gizi, kadar hemoglobin, ureum, dan kreatinin pasien konseling gizi hemodialisa
}

Kristiawan P. A. Nugroho ${ }^{1}$, Sarlina Palimbong ${ }^{2}$, Fransiska M. Santoso Putri ${ }^{1}$, Puji Astuti ${ }^{3}$, Ike Listiyowati ${ }^{3}$

${ }^{1}$ Program Studi S1 IImu Gizi, Fakultas Kedokteran dan Ilmu Kesehatan, Universitas Kristen Satya Wacana, Jl. Kartini No.11A, Salatiga, e-mail : kristiawan.nugroho@staff.uksw.edu

${ }^{2}$ Program Studi S1 Teknologi Pangan, Fakultas Kedokteran dan Ilmu Kesehatan, Universitas Kristen Satya Wacana, Jl. Kartini No. 11A, Salatiga

${ }^{3}$ Instalasi Gizi RSUD Ungaran, JI. Diponegoro No.125, Ungaran, Semarang, Jawa Tengah

\begin{abstract}
ABSTRAK
Latar belakang : Pasien yang menjalani terapi hemodialisa harus mengetahui jenis makanan yang boleh dikonsumsi, yakni makanan yang mengandung protein hewani, rendah kalium, dan rendah garam. Peran ahli gizi sangat dibutuhkan, salah satunya adalah memberikan konseling gizi terkait pengaturan pola makan. Penelitian yang pernah dilakukan oleh peneliti sebelumnya adalah mengenai pola makan pasien hemodialisa dan berbagai faktor yang mempengaruhi kepatuhan dietnya, tetapi belum ada yang mengkaji tentang hubungan status gizi, kadar hemoglobin, ureum, dan kreatinin pasien hemodialisa sebelum dan sesudah melakukan konseling gizi yang turut memiliki hubungan dengan pola makan dan kepatuhan diet pasien hemodialisa.

Tujuan : Tujuan penelitian ini adalah untuk menganalisis hubungan status gizi, kadar hemoglobin, ureum, dan kreatinin pasien hemodialisa sebelum dan sesudah melakukan konseling gizi di RSUD Ungaran.

Metode : Penelitian menggunakan metode observasional analitik dengan rancangan penelitian crosssectional. Penelitian dilaksanakan di RSUD Ungaran dengan total sampling sebanyak 30 pasien hemodialisa di Unit Hemodialisa. Data primer diperoleh dari pengisian data diri responden dan FFQ, observasi, serta wawancara. Data sekunder dikutip dari catatan medik responden meliputi kadar hemoglobin, ureum, dan kreatinin. Data dianalisis menggunakan SPSS dengan uji Paired T Test.

Hasil : Hasil analisis menunjukkan nilai probabilitas ureum pria $0,016<0,05$ dan ureum wanita - hemoglobin pria dan wanita - kreatinin pria dan wanita secara keseluruhan 0,000 <0,05 yang berarti bahwa rata-rata kadar hemoglobin, ureum, dan kreatinin sebelum dan sesudah melaksanakan konseling gizi berbeda.

Kesimpulan : Pemberian konseling gizi menunjukkan adanya perubahan terhadap status gizi seluruh pasien hemodialisa berdasarkan indikator berupa peningkatan kadar hemoglobin serta penurunan kadar ureum dan kreatinin; tetapi ketiganya tidak berada dalam kategori normal. Kadar hemoglobin, ureum, dan kreatinin tersebut berubah dalam jangka waktu satu bulan pasca pelaksanaan konseling gizi. Hal tersebut mengindikasikan bahwa upaya konseling gizi dengan teknik konseling gizi perseorangan memberikan manfaat positif bagi pasien untuk mendapatkan pengetahuan tentang pengaturan pola makan serta melaksanakan anjuran diet guna mengoptimalkan fungsi ginjal agar tidak bekerja berlebihan.
\end{abstract}

KATA KUNCI : status gizi, hemodialisa, perilaku makan, konseling gizi

\section{Nutrition status, hemoglobin, ureum, and creatinine on hemodialysis patients with nutrition counselling}

\begin{abstract}
Background : Patients who are undergoing hemodialysis therapy must know which foods that may be consumed including foods containing animal protein, low potassium, and low sodium. The role of nutritionists is needed to provide nutritional counseling related to dietary adjustment. Studies that have been conducted by previous researchers are about diet from hemodialysis patients and the various factors that affect dietary compliance of patients, but no one has been studying the relation related to
\end{abstract}


nutritional status, hemoglobin, ureum, and creatinine levels before and after doing a counseling that also has a relationship with diet and dietary compliance for hemodialysis patients.

Objectives : To analyze the relationship of nutritional status, hemoglobin, ureum, and creatinine levels of hemodialysis patients before and after nutritional counseling in RSUD Ungaran.

Methods : The study used a observational analytic method with cross-sectional approach. The research was conducted in Hemodialysis Unit of RSUD Ungaran with a total sampling of 30 hemodialysis patient. Primary data were obtained from respondent's data entry and FFQ, observation, and interviews. Secondary data were obtained from respondent's medical records include the level of hemoglobin, urea, and cretinine. Data were analyzed using SPSS programme with Paired $t$ Test.

Results : The results of SPSS analysis showed that probability value from urea men $0.016<0.05$ and urea women - hemoglobin men and women - creatinin men and women overall $0.000<0.05$, which means that the average levels of those components before and after doing a nutritional counseling is different.

Conclusions : A nutritional counseling indicate any change in the nutritional status of the entire hemodialysis patients, based on hemoglobin levels increased, while urea and creatinine levels decreased; but all those components are not in the normal category. Levels of hemoglobin, urea, and creatinine is changed within a period of one month after the implementation of individual nutritional counseling. It indicates that nutritional counseling efforts were given has a positive benefit for the patients to gain knowledge about dietary adjustments and implement the recommended diet in order to optimize the work of renal function excessively.

KEYWORDS : nutritional status, hemodialysis, eating behavior, nutritional counselling

\section{PENDAHULUAN}

Angka kejadian gagal ginjal di dunia secara global mencapai angka lebih dari 500 juta kasus. Sekitar 1,5 juta orang diantaranya harus menjalani hidup dengan bergantung pada rutinitas cuci darah (hemodialisis). Penyakit gagal ginjal kronik telah menyerang lebih dari 500 juta orang di seluruh dunia dan merupakan masalah kesehatan masyarakat yang utama (1). Hasil survei Badan Kesehatan dan Nutrisi Amerika Serikat menyebutkan bahwa ada 26 juta manusia yang menderita gagal ginjal kronik di Amerika Serikat (2). Indonesia termasuk negara dengan tingkat penderita gagal ginjal yang cukup tinggi. Peningkatan penderita penyakit gagal ginjal di Indonesia mencapai angka 20\% (3).

Penyakit ginjal kronik merupakan permasalahan bidang nefrologi dengan angka kejadian masih cukup tinggi, etimologi luas dan kompleks, sering diawali tanpa keluhan maupun gejala klinis kecuali sudah terjun pada stadium terminal (gagal ginjal terminal) (3). Gagal ginjal adalah suatu kondisi dimana ginjal tidak dapat menjalankan fungsinya secara normal. Pada gagal ginjal kronik, penurunan fungsi ginjal terjadi secara perlahan. Proses penurunan fungsi ginjal dapat berlangsung terus selama berbulan-bulan atau bertahun-tahun sampai ginjal tidak dapat berfungsi sama sekali dan bersifat irreversible, sampai pada satu derajat yang memerlukan pengganti ginjal yang tetap berupa hemodialisis atau transplantasi ginjal $(3,4)$.

Hemodialisis merupakan salah satu metode terapi yang digunakan untuk mengeluarkan cairan dan produk limbah dari dalam tubuh (5). Hemodialisis yang tidak adekuat dapat menjadi penyebab penting terjadinya malnutrisi. Untuk mengukur keadaan gizi apakah ada atau tidak malnutrisi pada pasien gagal ginjal kronik, dianjurkan melihat beberapa parameter untuk menyimpulkannya, diantaranya adalah asupan makan, biokimiawi, pemeriksaan klinis, dan antropometrik (6).

Keberhasilan pasien dalam menjalani hemodialisis didasarkan pada unsur-unsur yang beragam, antara lain kepatuhan pasien dalam pembatasan cairan, rutin dalam menjalani hemodialisis, pengelolaan diri pasien, dan pemberdayaan pasien (7). Kaitannya dengan faktor konsumsi pangan, asupan makan pasien penyakit ginjal kronik biasanya rendah karena 
terjadi penurunan nafsu makan, timbul rasa mual, dan diikuti dengan muntah yang dapat berpengaruh terhadap penurunan berat badan penderita (1). Sehubungan dengan konteks tersebut, peran ahli gizi sebagai konselor bertujuan untuk memberikan konseling gizi dalam hal mengubah perilaku makan pasien hemodialisis agar dapat menjadi lebih baik dan mempertahankan atau memperbaiki status gizi pasien hemodialisis.

Tujuan dilakukannya konseling gizi adalah memberikan edukasi untuk memahami dan mampu merubah perilaku diet sesuai dengan yang dianjurkan oleh konselor (8). Melalui konseling gizi, pasien dapat mengetahui makanan apa yang seharusnya dikonsumsi dan tidak seharusnya dikonsumsi terkait penyakit gagal ginjal kronik dengan hemodialisis. Pemilihan makanan yang tepat akan memberikan dampak positif terkait dengan perbaikan status gizi pasien hemodialisa. Hasil yang diharapkan dari konseling gizi adalah adanya penyampaian pengetahuan dari ahli gizi ke masyarakat dapat memahami tentang gizi dan sikap masyarakat terhadap masalah gizi yang dihadapinya (9).

Data dari Unit Hemodialisa RSUD Ungaran, Jawa Tengah menyatakan bahwa pada tahun 2017 , terdapat 39 orang pasien gagal ginjal yang mendapatkan terapi hemodialisa. Pelayanan konsultasi gizi secara personal/ perseorangan diberikan setelah pasien melaksanakan hemodialisis. Konsultasi gizi yang diberikan kepada pasien yang menderita gagal ginjal kronik dan yang sedang menjalani terapi hemodialisis bertujuan agar pasien dapat tetap bisa mengatur dan menjaga pola makan di rumah dan keberadaan status gizi pasien tetap berada dalam tingkatan normal. Dengan konsultasi ini, peneliti dapat mengetahui tentang hal - hal apa saja yang menjadi masalah saat pasien melakukan diet dan peneliti juga dapat mengetahui sejauh mana pemahaman pasien tentang diet yang sedang dijalankan. Sebelum dilakukan penelitian, pasien hemodialisa mendapat konsultasi gizi secara berkelompok. Pada kenyataannya, pasien yang melakukan konsultasi gizi, status gizinya tidak begitu berbeda dengan pasien yang tidak melakukan konsultasi gizi. Berdasarkan latar belakang tersebut, maka dilakukan penelitian untuk mengkaji tentang status gizi serta kadar ureum dan kreatinin pasien hemodialisis sebelum dan sesudah melakukan konseling gizi di RSUD Ungaran, Jawa Tengah.

\section{BAHAN DAN METODE}

Metode penelitian yang digunakan adalah observational analitik dengan rancangan crosssectional untuk menjelaskan hubungan status gizi, kadar hemoglobin, kadar ureum, dan kadar kreatinin pasien hemodialisa sebelum dan sesudah melakukan konseling gizi di RSUD Ungaran $(10,11)$. Penelitian dilakukan di Unit Hemodialisa RSUD Ungaran, Jawa Tengah pada bulan Januari sampai Februari 2017. Responden dalam penelitian ini berjumlah 30 pasien (total sampling) yang menjalani hemodialisis di RSUD Ungaran. Para responden sebelumnya telah mendapatkan konseling gizi oleh ahli gizi setempat, namun dilakukan secara bersamaan (tidak perseorangan). Kriteria khusus responden untuk penelitian ini adalah pasien dengan diagnosa gagal ginjal kronik, melakukan hemodialisis secara rutin di RSUD Ungaran $\geq 6$ bulan, berusia $\geq 20$ tahun, menjalani rawat jalan di RSUD Ungaran, mampu berkomunikasi dengan baik, dan bersedia menjadi responden.

Perolehan data berupa data primer dan sekunder. Data primer diambil dengan melakukan pengisian identitas diri responden oleh peneliti, termasuk di dalamnya usia, tinggi badan, dan berat badan untuk menentukan IMT; observasi dan wawancara langsung dengan responden serta mengisi food frequency quantitative (FFQ) yang sudah berisi data nama makanan dan kolom berupa frekuensi seberapa sering pasien mengonsumsi makanan tersebut, mulai dari sumber karbohidrat, protein, sayuran, buah-buahan, lemak, dan minyak. Data sekunder dikutip dari catatan medik responden (hasil pemeriksaan laboratorium meliputi kadar hemoglobin, ureum, dan kreatinin) sebagai indikator untuk mengetahui status gizi, ureum, dan kreatinin pasien yang menjalani hemodialisa.

Analisis data dilakukan untuk mengetahui pengaruh perbedaan status gizi berdasarkan kadar hemoglobin, kadar ureum, dan kadar 
kreatinin; serta perilaku makan sebelum dan sesudah perlakuan pada kelompok terpilih. Analisis data statistik menggunakan program SPSS 17 dengan uji paired t test, yakni membandingkan hasil pemeriksanaan klinis dari ketiga parameter tersebut saat sebelum dan sesudah melaksanakan konseling oleh peneliti yang didampingi oleh ahli gizi RSUD Ungaran selama 2 minggu. Hipotesis penelitian untuk pengujian adalah $\mathrm{H}_{0}=$ rata-rata kadar ureum dan kreatinin sebelum dan sesudah melaksanakan konseling gizi adalah sama serta $\mathrm{H}_{1}=$ rata-rata kadar ureum dan kreatinin sebelum dan sesudah melaksanakan konseling gizi adalah berbeda. Pengambilan keputusan untuk hipotesis tersebut didasarkan pada perbandingan dengan nilai probabillitas dari uji t yang digunakan, yakni apabila probabilitas $>0,05=\mathrm{H}_{0}$ diterima; apabila probabilitas $<0,05=\mathrm{H}_{0}$ ditolak (12).

\section{HASIL PENELITIAN}

\section{Karakteristik Responden}

Dari 39 orang pasien yang melakukan hemodialisis di RSUD Ungaran, hanya 30 orang pasien yang bersedia menjadi responden. Tabel 1 berisi karakteristik responden berdasarkan jenis kelamin, usia, status gizi, dan jenis pekerjaan. Persentase responden wanita sebanyak 53,3\% (16 orang), sedangkan responden pria sebesar $46,7 \%$ (14 orang). Sebanyak $56,7 \%$ berada pada rentang usia 41 - 60 tahun, sisanya berada pada rentang usia $<40$ tahun $(26,6 \%)$ dan $>60$ tahun $(16,7 \%)$. Hasil penghitungan indeks massa tubuh (IMT) untuk masyarakat di Indonesia, sebagian besar responden berada dalam status gizi normal $(76,7 \%)$ dan hanya 1 orang saja $(3,3 \%)$ dengan status gizi kurus serta 6 orang responden (20\%) yang berada dalam kategori gemuk. Berdasarkan jenis pekerjaan responden, sebanyak $26,6 \%$ (8 orang) dan $6,6 \%$ (2 orang) responden masing-masing bekerja sebagai wiraswatawan dan PNS, sedangkan responden lainnya tidak bekerja. Namun, diantara responden yang tidak bekerja tersebut, 1 orang responden masih menerima uang bulanan dari uang pensiun, sedangkan 19 orang responden lainnya $(63,3 \%)$ tidak mendapatkan pemasukan bulanan karena berprofesi
Tabel 1. Distribusi subjek penelitian berdasarkan jenis kelamin, usia, IMT Indonesia, dan pekerjaan

\begin{tabular}{lcc}
\hline \multicolumn{1}{c}{ Jenis Kelamin } & Frekuensi & $\begin{array}{c}\text { Persentase } \\
(\%)\end{array}$ \\
\hline Jenis kelamin & 16 & 53,3 \\
$\quad$ Pria & 14 & 46,7 \\
Wanita & 30 & 100 \\
$\quad$ Total & & \\
Usia & 8 & 26,6 \\
$21-40$ tahun & 17 & 56,7 \\
$41-60$ tahun & 5 & 16,7 \\
$>60$ tahun & 30 & 100 \\
Total & & \\
Status gizi & 1 & 3,3 \\
Kurus (17 - 18,5) & 23 & 76,7 \\
Normal $(18,5-25,0)$ & 6 & 20 \\
Gemuk $(>25)$ & 30 & 100 \\
Total & & \\
Jenis pekerjaan & 1 & 3,3 \\
Pensiunan & 13 & 43,3 \\
Ibu rumah tangga & 8 & 26,6 \\
Wiraswasta & 2 & 6,6 \\
Pns & 6 & 20 \\
Pengangguran & 30 & 100 \\
Total & & \\
\hline
\end{tabular}

sebagai ibu rumah tangga (IRT) dan pengangguran. Gambaran status gizi, kadar hemoglobin, ureum, dan kreatinin pasien hemodialisa

Secara keseluruhan, gambaran status gizi baik untuk pasien pria maupun wanita, kadar hemoglobin, ureum, dan kreatinin mengalami perubahan. Terjadi peningkatan untuk kadar hemoglobin serta penurunan untuk kadar ureum dan kadar kreatinin setelah melakukan konseling gizi selama 2 minggu (Tabel 2).

Kadar hemoglobin pasien pria sebelum konseling gizi berkisar antara 4,6 - 10,1 g/dL dengan rataan $8,4 \mathrm{~g} / \mathrm{dL}$. Setelah melaksanakan konseling, kelompok pasien pria mengalami peningkatan kadar hemoglobin berkisar antara 7,7-12,6 g/dL dengan rataan 10,3 g/dL. Meskipun terjadi perubahan kadar hemoglobin sebesar $1,9 \mathrm{~g} / \mathrm{dL}$ dari rataan $8,4 \mathrm{~g} / \mathrm{dL}$ menjadi 10,3 g/dL, angka tersebut tidak termasuk ke dalam kategori normal dalam kisaran $13,5-18 \mathrm{~g} /$ dL. Kondisi serupa terjadi pada pasien wanita, kadar hemoglobin sebelum melaksanakan konseling gizi berkisar antara 6,5-13,2 g/dL dengan rataan kadar hemoglobin sebesar $8,7 \mathrm{~g} / \mathrm{dL}$. Kadar hemoglobin 
tersebut mengalami peningkatan mencapai rataan 10,8 g/dL dari kisaran 9,4 - 13,4 g/dL. Kadar hemoglobin mengalami peningkatan sebesar 2,1 $\mathrm{g} / \mathrm{dL}$ dari $8,7 \mathrm{~g} / \mathrm{dL}$ sebelum konseling gizi menjadi $10,8 \mathrm{~g} / \mathrm{dL}$ setelah melaksanakan konseling gizi. Sama halnya dengan kadar hemoglobin pada pria, meskipun terjadi perubahan berupa peningkatan kadar hemoglobin, angka tersebut tidak termasuk ke dalam kategori normal $(12-16 \mathrm{~g} / \mathrm{dL})$. Peningkatan kadar hemoglobin pada masing-masing pasien, dapat dilihat pada Gambar 1 dan Gambar 2.

Sama halnya dengan kadar hemoglobin, pengukuran terhadap kadar ureum responden mengalami perubahan berupa penurunan kadar ureum mencapai $43 \mathrm{mg} / \mathrm{dL}$ untuk pasien pria dari rataan $166,1 \mathrm{mg} / \mathrm{dL}$ sebelum konseling gizi menjadi $123,1 \mathrm{mg} / \mathrm{dL}$ setelah melaksanakan konseling gizi dari kisaran 97 - $321 \mathrm{mg} / \mathrm{dL}$ menjadi 87 - $171 \mathrm{mg} /$
dL. Pada kelompok pasien wanita, kadar ureum mengalami penurunan mencapai $50 \mathrm{mg} / \mathrm{dL}$ dari rataan $168,2 \mathrm{mg} / \mathrm{dL}$ menjadi $118,2 \mathrm{mg} / \mathrm{dL}$ setelah mengikuti konseling gizi dari Instalasi Gizi RSUD Ungaran. Kadar ureum pada responden wanita berkisar antara $99-216 \mathrm{mg} / \mathrm{dL}$ sebelum konseling gizi dan turun menjadi kisaran $90-165 \mathrm{mg} / \mathrm{dL}$ setelah melaksanakan konseling gizi selama 2 minggu (Tabel 2). Meskipun terjadi perubahan berupa penurunan kadar ureum pada seluruh responden, angka tersebut tidak termasuk ke dalam kategori normal dalam kisaran $10-50 \mathrm{mg} /$ dL (Tabel 3). Untuk penurunan kadar ureum pada masing-masing pasien, dapat dilihat pada Gambar 3 dan Gambar 4.

Kadar kreatinin secara keseluruhan juga mengalami penurunan mencapai $3,37 \mathrm{mg} / \mathrm{dL}$ untuk responden pria dari rataan $13,84 \mathrm{mg} / \mathrm{dL}$ menjadi 10,47

Tabel 2. Hasil pemeriksaan kadar hemoglobin, ureum, dan kreatinin pasien hemodialisa di RSUD Ungaran sebelum dan sesudah melaksanakan konseling gizi

\begin{tabular}{lccccccc}
\hline \multirow{2}{*}{$\begin{array}{c}\text { Perlakuan } \\
\text { konseling }\end{array}$} & \multirow{2}{*}{ Pasien } & \multicolumn{5}{c}{ Pemeriksaan Laboratorium } \\
\cline { 3 - 7 } & & \multicolumn{2}{c}{ Hemoglobin (g/dL) } & Ureum $(\mathbf{m g} / \mathbf{d L})$ & \multicolumn{2}{c}{ Kreatinin $(\mathbf{m g} / \mathbf{d L})$} \\
\cline { 3 - 7 } & Kisaran & Rataan & Kisaran & Rataan & Kisaran & Rataan \\
\hline \multirow{2}{*}{ Sebelum } & Pria & $4,6-10,1$ & 8,4 & $97-321$ & 166,1 & $5,6-23,19$ & 13,84 \\
& Wanita & $6,5-13,2$ & 8,7 & $99-216$ & 168,2 & $5,84-20,27$ & 10,73 \\
\multirow{2}{*}{ Sesudah } & Pria & $7,7-12,6$ & 10,3 & $87-171$ & 123,1 & $3,1-15,45$ & 10,47 \\
& Wanita & $8,4-13,4$ & 10,8 & $90-165$ & 118,2 & $3,12-9,46$ & 7,09 \\
\hline
\end{tabular}

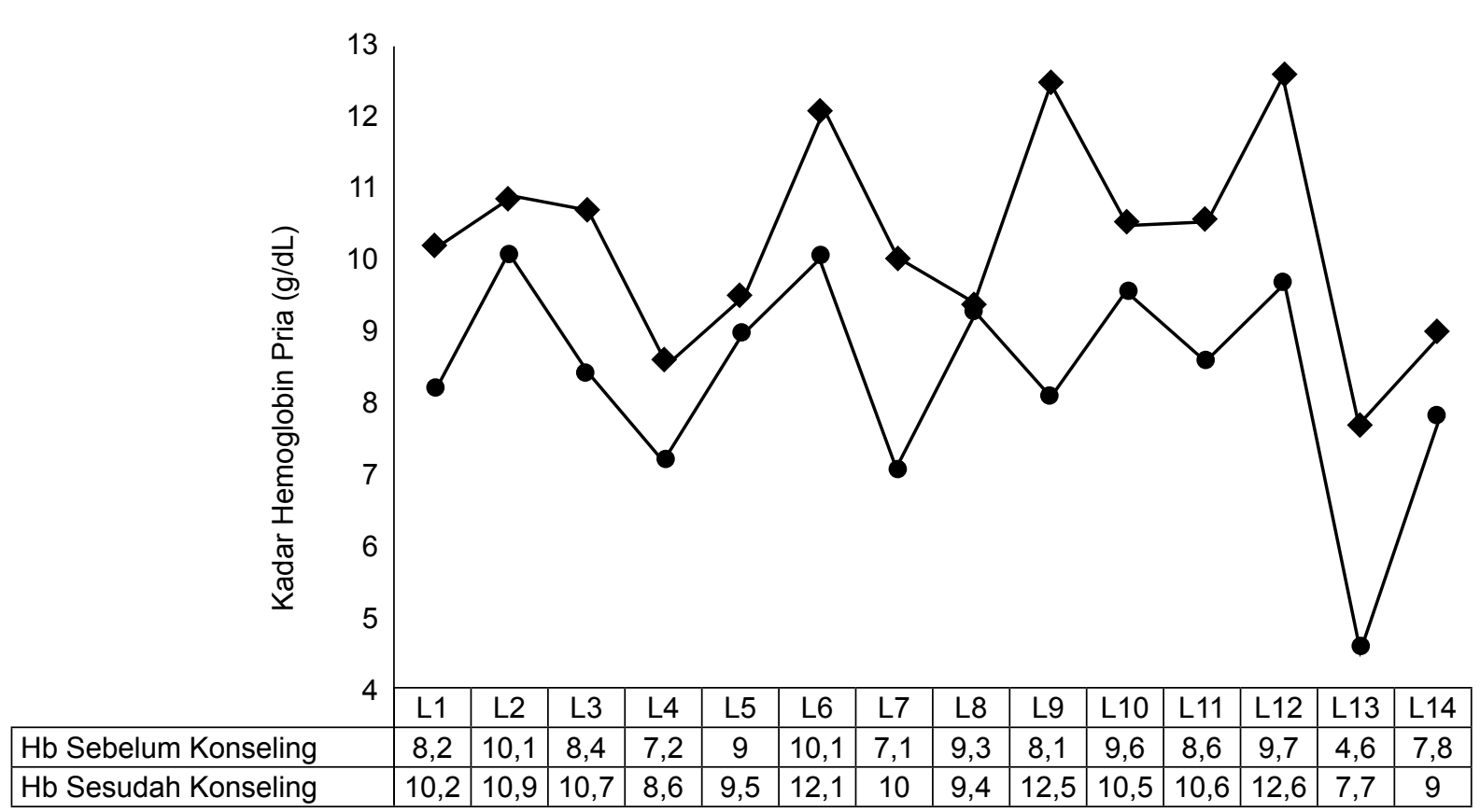

Gambar 1. Peningkatan kadar hemoglobin pasien pria sebelum dan sesudah konseling gizi (g/dL) 


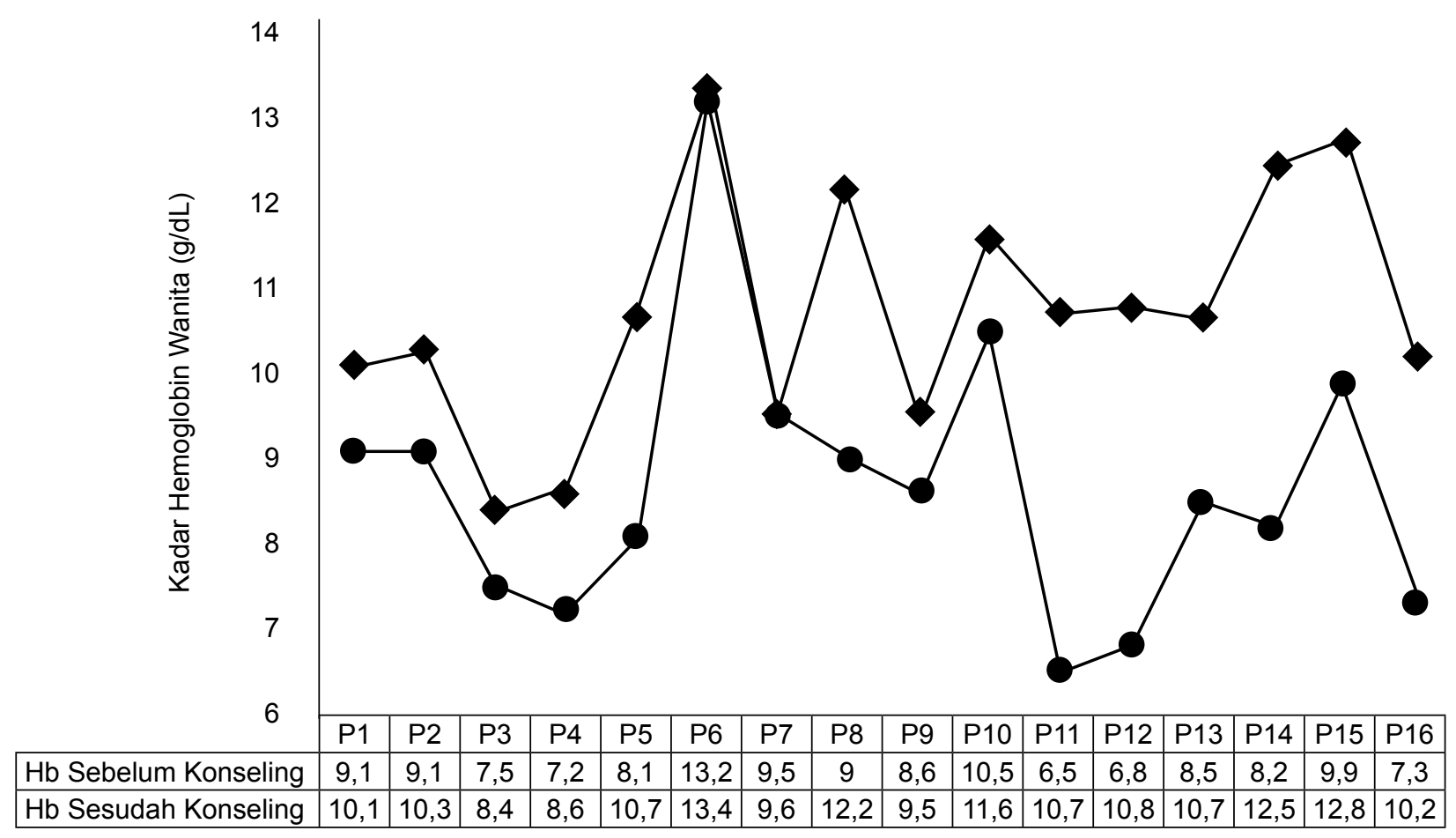

Gambar 2. Peningkatan kadar hemoglobin pasien wanita sebelum dan sesudah konseling gizi (gr/dl)

$\mathrm{mg} / \mathrm{dL}$ serta 3,64 $\mathrm{mg} / \mathrm{dL}$ untuk responden wanita dari rataan $10,73 \mathrm{mg} / \mathrm{dL}$ menjadi $7,09 \mathrm{mg} / \mathrm{dL}$ setelah mengikuti konseling gizi selama 2 minggu (Tabel 2). Meskipun terjadi perubahan berupa penurunan kadar kreatin pada seluruh responden, angka tersebut tidak termasuk ke dalam kategori normal dalam kisaran 0,5 $-1,5 \mathrm{mg} / \mathrm{dL}$. Untuk penurunan kadar kreatinin pada masing-masing pasien, dapat dilihat pada Gambar 5 dan Gambar 6.

Berdasarkan hasil uji Paired t Test (Tabel 3), pelaksanaan konseling gizi memberikan perubahan signifikan terhadap kadar hemoglobin, ureum, dan kreatinin dari seluruh responden dengan nilai probabilitas (Sig. 2-tailed) $<0,05\left(\mathrm{H}_{\circ}\right.$ ditolak) yang menyatakan bahwa rata-rata kadar hemoglobin, ureum, dan kreatinin sebelum dan

Tabel 3. Hasil uji Paired T Test terhadap kadar hemoglobin, ureum, dan kreatinin pada responden hemodialisa di RSUD Ungaran, Jawa Tengah sebelum dan setelah melaksanakan konseling gizi

\begin{tabular}{cccc}
\hline \multirow{2}{*}{ Pasien } & \multicolumn{3}{c}{ Paired $t$ Test (Sig. 2-tailed) } \\
\cline { 2 - 4 } & Hemoglobin & Ureum & Kreatinin \\
\hline Pria & 0,000 & 0,016 & 0,000 \\
Wanita & 0,000 & 0,000 & 0,000 \\
\hline
\end{tabular}

sesudah melaksanakan konseling gizi berbeda $\left(\mathrm{H}_{1}\right.$ diterima).

Konsumsi nasi putih sebagai sumber karbohidrat masih menjadi pilihan utama bagi semua pasien hemodialisa, baik sebelum maupun sesudah menjalani konseling gizi. Jenis protein hewani yang dikonsumsi sama, hanya terjadi perubahan jumlah responden dari masing-masing $43,3 \%$ daging ayam (13 orang), $16,7 \%$ daging sapi (5 orang), $16,7 \%$ telur ayam (5 orang), serta $23,3 \%$ ikan lele (7 orang) sebelum diberikan konseling menjadi masing $73,3 \%$ daging ayam (22 orang), 13,3\% daging sapi (4 orang), 6,7\% telur ayam (2 orang), serta $6,7 \%$ ikan lele (2 orang) setelah melakukan konseling gizi. Untuk konsumsi lemak dan minyak, sebagian besar responden $(53,3 \%)$ mengonsumsi santan dan sisanya mengonsumsi makanan yang digoreng dan mengandung campuran margarin sebelum diberikan konseling gizi. Setelah dilakukan konseling gizi, konsumsi makanan bersantan dan mengandung margarin berkurang, namun konsumsi makanan yang digoreng meningkat $(66,7 \%)$. Hal ini dapat dilihat pada tabel 4 yang menunjukan berapa jumlah pasien yang mengkonsumsi pilihan - pilihan 


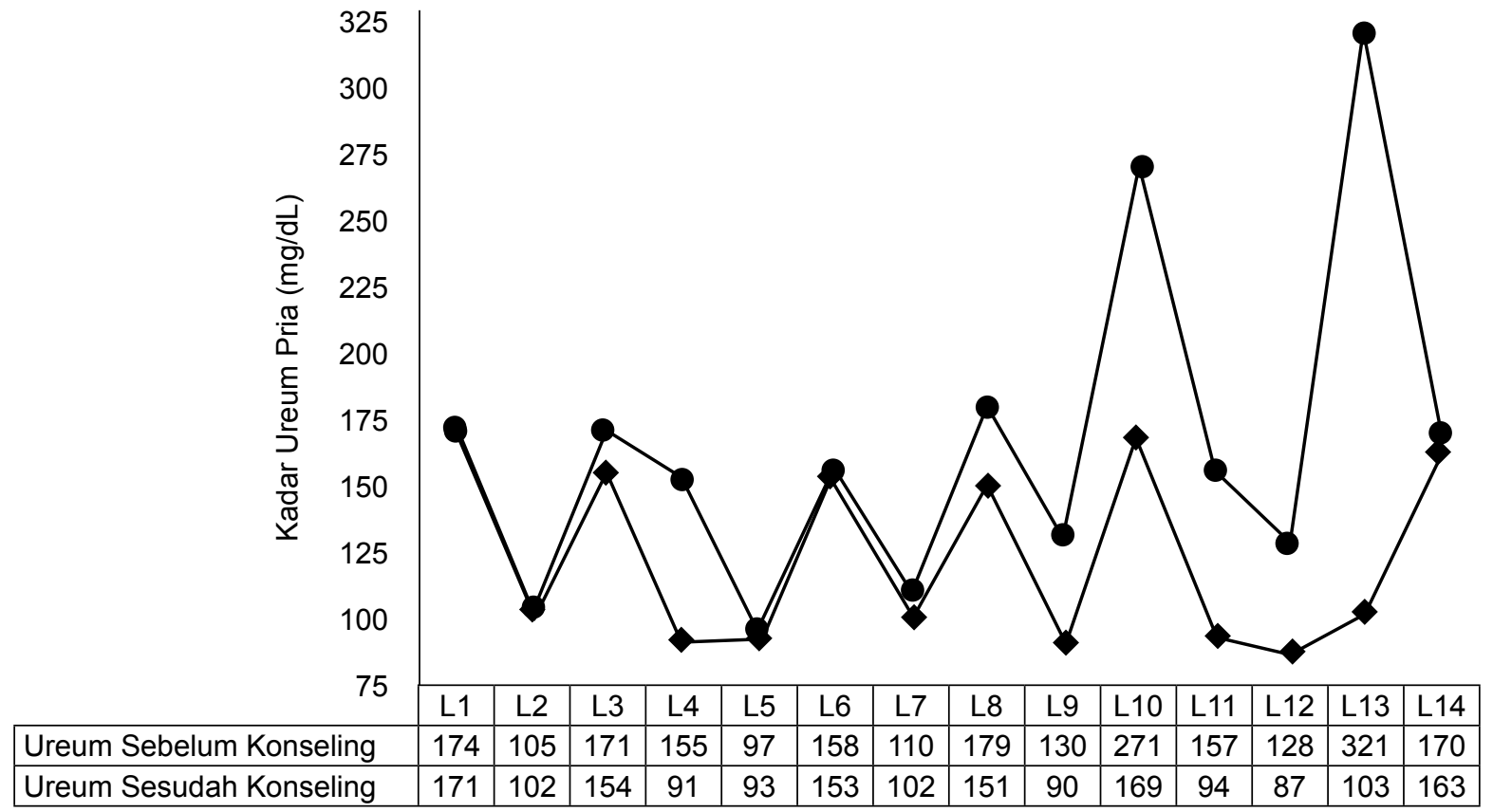

Gambar 3. Penurunan kadar ureum pasien pria sebelum dan sesudah konseling gizi (mg/dL)

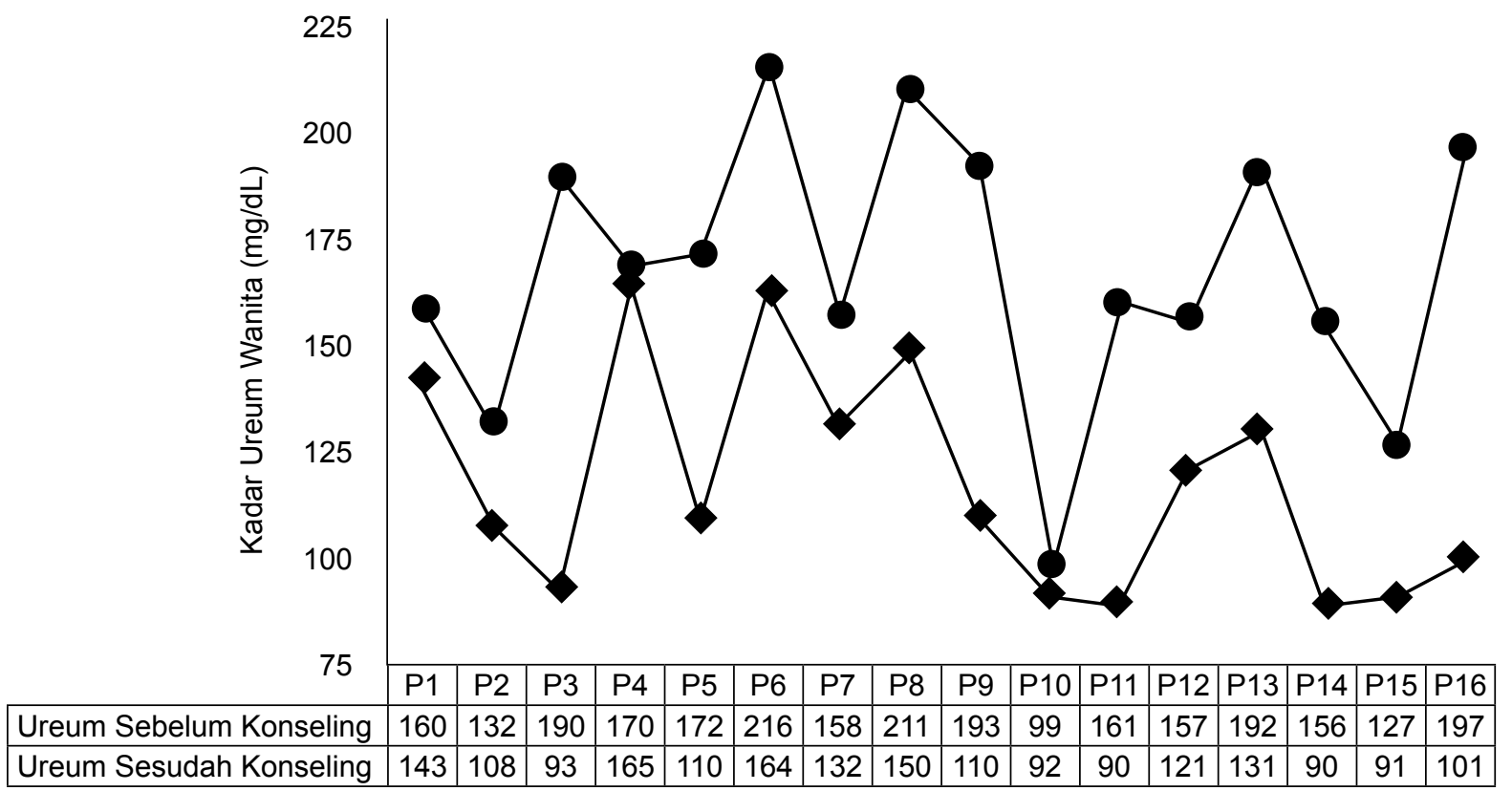

Gambar 4. Penurunan kadar ureum pasien wanita sebelum dan sesudah konseling gizi (mg/dL)

makanan yang ada di dalam tabel ini sebelum dilakukan konseling dan apakah ada perubahan dalam pemilihan jenis makanan setelah dilakukan konseling.

Selain mengonsumsi jenis makanan yang mengandung karbohidrat, protein, dan lemak, pasien hemodialisa juga mengonsumsi sayuran dan buah-buahan guna mendapatkan asupan serat, mineral, dan vitamin. Sebanyak $50 \%$ responden (15 orang) mengonsumsi sawi putih dan sisanya mengonsumsi jenis sayur bayam, wortel, bayam, dan kangkung sebelum melakukan konseling gizi. Setelah diberikan konseling gizi, pilihan sayur yang dikonsumsi cenderung sama seperti 
Tabel 4. Asupan sumber bahan makanan responden sebelum dan sesudah melakukan konseling gizi berdasarkan hasil FFQ

\begin{tabular}{|c|c|c|c|c|}
\hline \multirow{3}{*}{ Bahan Makanan } & \multicolumn{4}{|c|}{ Konseling Gizi } \\
\hline & \multicolumn{2}{|c|}{ Sebelum } & \multicolumn{2}{|c|}{ Sesudah } \\
\hline & Jumlah & $\%$ & Jumlah & $\%$ \\
\hline \multicolumn{5}{|l|}{ Karbohidrat } \\
\hline Nasi putih & 30 & 100 & 30 & 100 \\
\hline Total & 30 & 100 & 30 & 100 \\
\hline \multicolumn{5}{|l|}{ Protein Hewani } \\
\hline Daging ayam & 13 & 43,3 & 22 & 73,3 \\
\hline Daging sapi & 5 & 16,7 & 4 & 13,3 \\
\hline Telur ayam & 5 & 16,7 & 2 & 6,7 \\
\hline Ikan Lele & 7 & 23,3 & 2 & 6,7 \\
\hline Total & 30 & 100 & 30 & 100 \\
\hline \multicolumn{5}{|l|}{ Protein Nabati } \\
\hline Tempe & - & - & 15 & 50 \\
\hline Tahu & - & - & 15 & 50 \\
\hline Tempe \& tahu & 30 & 100 & & \\
\hline Total & 30 & 100 & 30 & 100 \\
\hline \multicolumn{5}{|l|}{ Lemak dan Minyak } \\
\hline Santan & 16 & 53,3 & 8 & 26,6 \\
\hline Minyak Goreng & 7 & 23,3 & 20 & 66,7 \\
\hline Margarin & 7 & 23,3 & 2 & 6,7 \\
\hline Total & 30 & 100 & 30 & 100 \\
\hline \multicolumn{5}{|l|}{ Sayuran } \\
\hline Sawi putih & 15 & 50 & 15 & 50 \\
\hline Wortel & 5 & 16,7 & 5 & 16,7 \\
\hline Bayam & 5 & 16,7 & - & - \\
\hline Kangkung & 5 & 16,7 & 5 & 16,7 \\
\hline Labu siam & - & - & 5 & 16,7 \\
\hline Total & 30 & 100 & 30 & 100 \\
\hline \multicolumn{5}{|l|}{ Buah-buahan } \\
\hline Pepaya & 25 & 83,3 & 25 & 83,3 \\
\hline Apel & 3 & 10 & 3 & 10 \\
\hline Mangga & 1 & 3,3 & 1 & 3,3 \\
\hline Jeruk & 1 & 3,3 & 1 & 3,3 \\
\hline Total & 30 & 100 & 30 & 100 \\
\hline
\end{tabular}

sebelum mendapatkan konseling gizi, hanya mengganti pilihan bayam dengan labu siam untuk $16,7 \%$ responden (5 orang). Pasien hemodialisa lebih memilih mengonsumsi pepaya $(83,3 \%)$ dibandingkan dengan jenis buah-buahan lain seperti apel, mangga, dan jeruk baik sebelum maupun sesudah melakukan konseling gizi.

\section{BAHASAN}

Status gizi berdasarkan penghitungan IMT menunjukkan dominan responden ada dalam kategori normal, namun masih ditemukan responden dalam kategori kurus dan gemuk (Tabel 1). Penyebab responden berada dalam status gizi kurus adalah berkurangnya nafsu makan karena rasa mual dan muntah akibat terapi hemodialisis yang dilakukan. Responden yang mengalami kegemukan disebabkan oleh frekuensi makan yang tidak teratur, lebih dari tiga kali makan besar dalam sehari. Melalui pemberian konseling gizi ini diharapkan dapat meningkatkan status gizi pasien dari kurus menjadi normal, menurunkan derajat status gizi pasien dari gemuk menjadi normal, dan tetap mempertahankan kondisi normal pasien dengan cara menjaga pola makan dan tetap mengonsumsi makan serta minuman sesuai dengan takaran yang sudah ditentukan oleh ahli gizi atau konselor gizi.

Pemilihan jenis makanan untuk pasien hemodialisa di RSUD Ungaran dipengaruhi oleh jenis pekerjaan dan penghasilan pasien maupun keluarga pasien (Tabel 1). Bagi pasien atau keluarga pasien yang tidak bekerja, penyediaan makanan disesuaikan dengan ketersediaan bahan makanan di rumah atau sesuai dengan kemampuan keluarga untuk membeli bahan makanan, namun tetap disesuaikan dengan anjuran ahli gizi saat melaksanakan konseling. Bagi pasien atau keluarga pasien yang bekerja dan memiliki pendapatan finansial yang cukup, penyediaan makanan juga disesuaikan dengan ketersediaan bahan makanan di rumah bahkan dapat membeli jenis makanan pengganti lain dengan alasan jenuh mengonsumsi jenis makanan yang sama secara rutin, namun tetap disesuaikan dengan anjuran ahli gizi saat melaksanakan konseling, misalnya konsumsi tempe diganti dengan telur ayam.

Hemoglobin berisi zat besi yang terdapat di dalam eritrosit dan bertugas dalam pengangkutan oksigen ke seluruh bagian tubuh. Konsekuensi dari peningkatan kadar hemoglobin dalam darah adalah mampu meningkatkan eritropoetin yang berfungsi mengontrol produksi eritrosit. Eritropoetin merupakan hormon yang dihasilkan oleh ginjal. Peningkatan sel darah merah pada pasien hemodialisa dapat mencegah terjadinya anemia yang mengakibatkan pasien hemodialisa kelelahan, pucat, dan lemah $(13,14)$. 


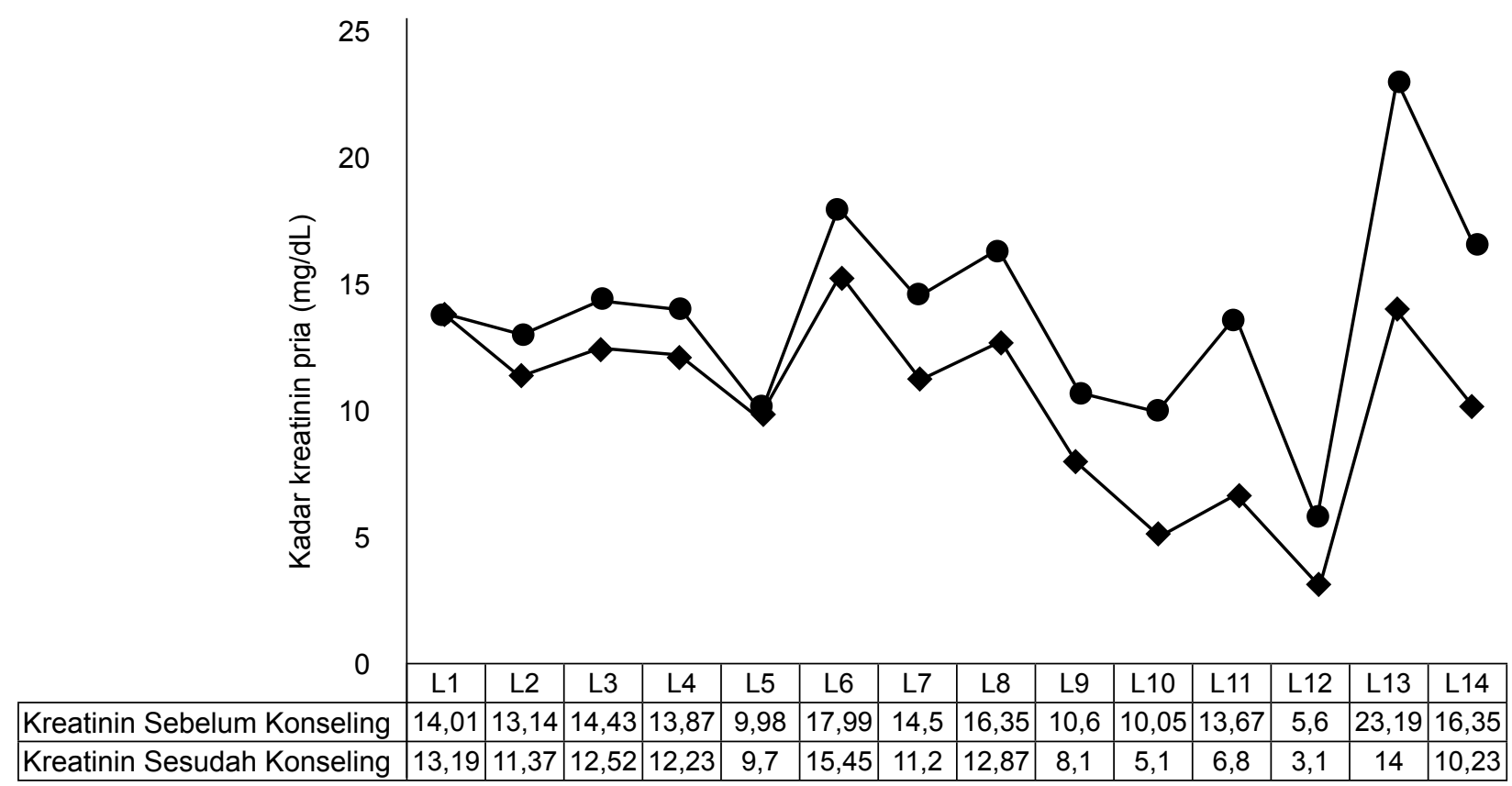

Gambar 5. Penurunan kadar kreatinin pasien pria sebelum dan sesudah konseling gizi (mg/dL)

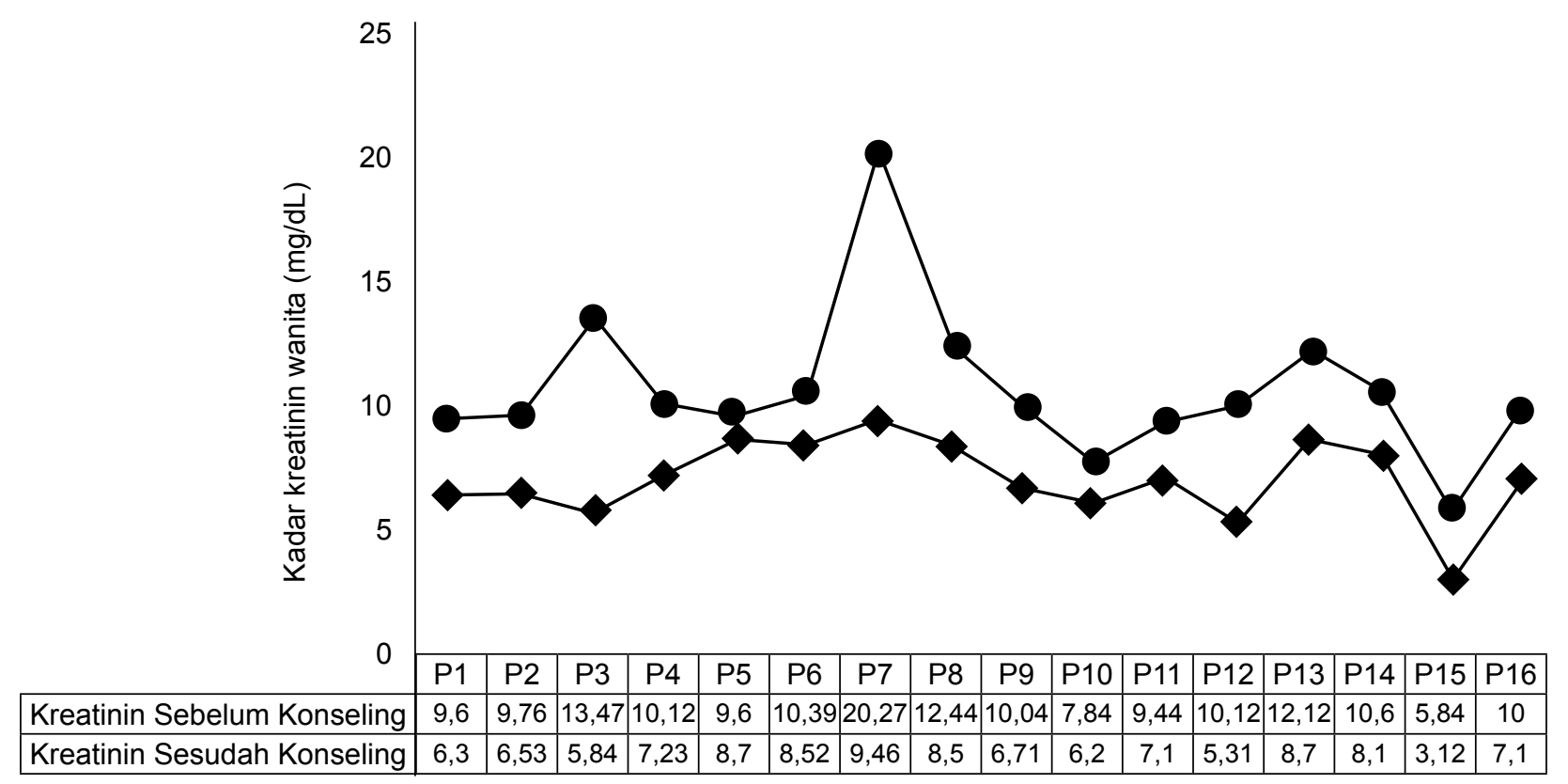

Gambar 6. Penurunan kadar kreatinin pasien wanita sebelum dan sesudah konseling gizi (mg/dL)

Ureum merupakan senyawa amonia yang bersumber dari metabolisme asam amino yang diubah oleh hati menjadi ureum. Molekul ureum yang kecil dapat dengan mudah berdifusi ke cairan ekstra sel, kemudian dipekatkan, dan diekskresikan melalui urin sekitar $25 \mathrm{~g} / \mathrm{hari}$. Pada pasien hemodialisa, kadar ureum dalam darah akan meningkat karena terjadi peningkatan katabolisme protein (faktor prerenal) maupun gagal ginjal akut (faktor renal) (15).

Kadar ureum serum mencerminkan keseimbangan antara produksi dan ekskresi. Metode penetapannya adalah dengan mengukur nitrogen atau sering disebut blood urea nitrogen (BUN). Nilai BUN akan meningkat apabila seseorang mengonsumsi protein dengan jumlah berlebih, 
namun pangan yang baru disantap tidak akan berpengaruh terhadap nilai ureum pada saat manapun. Nilai BUN inilah yang menyebabkan adanya hubungan asupan protein dengan kadar ureum (16).

Ureum dipengaruhi isi protein dalam makanan, sedangkan kreatinin ditentukan oleh banyaknya masa otot (laju katabolisme protein). Selain itu, dipengaruhi pula oleh aktivitas metabolisme tubuh manusia, misalnya akan meningkat apabila seseorang mengalami demam atau jika terjadi infeksi (17). Tingginya kadar ureum dalam darah yang tidak dapat dikeluarkan dari dalam tubuh karena menurunnya fungsi ginjal dapat menjadi toksik bagi tubuh karena dapat menginaktifkan eritoprotein sehingga mengakibatkan penurunan produksi sel darah merah dan menimbulkan anemia (14).

Setelah melalui pelaksanaan konseling gizi, pasien sudah dapat mengatur pola makan sehingga indikasi kadar kreatinin menurun, meskipun nilai kreatinin untuk seluruh pasien masih berada jauh di atas batas normal kadar kreatinin yang ditetapkan. Kreatinin merupakan produk akhir dari metabolisme kreatin otot dan kreatin fosfat yang disintesis dalam hati. Secara umum kreatinin dapat ditemukan dalam otot rangka dan darah, kemudian diekskresikan dalam urin (15).

Apabila ditemukan adanya kenaikan kadar kreatinin dalam darah mengindikasikan terjadinya penurunan klirens kreatinin dan laju filtrasi glomerulus. Asupan daging matang dalam jumlah banyak akan meningkatkan kadar kreatinin serum karena terjadi penambahan kreatinin eksogen. Setiap 1 gram daging yang dimakan akan menghasilkan 3,5-5,0 mg kreatinin (18). Ginjal akan membuang kreatinin dari darah ke urin. Bila fungsi ginjal terutama nefron menurun hingga $50 \%$, kadar kreatinin di dalam darah akan meningkat. Fungsi ginjal (khususnya glomerulus) inilah yang menyebabkan adanya hubungan asupan protein dengan kadar kreatinin $(19,20)$. Konsumsi jenis makanan hewani berupa daging sapi secara berlebih dapat menjadi salah satu faktor risiko peningkatan kadar kreatinin (15).

Kadar ureum dan kreatinin tertinggi ditemukan dalam kelompok pasien pria, masing-masing mencapai $321 \mathrm{mg} / \mathrm{dL}$ dan $23,19 \mathrm{mg} / \mathrm{dL}$ sebelum melaksanakan konseling gizi. Responden mengaku mengonsumsi suplemen protein secara rutin guna menunjang performa fisik dalam berlatih fitness (gym) di pusat kebugaran sebelum dinyatakan mengalami gagal ginjal kronis. Hasil pemeriksaan kadar kandungan ureum dan kreatinin menunjukkan hasil lebih tinggi dibandingkan pasien hemodialisa lainnya karena saat pemeriksaan berlangsung, responden masih mengonsumsi suplemen tersebut namun tidak serutin sebelumnya. Penurunan kadar ureum (103 mg/dL) dan kreatinin ( $14 \mathrm{mg} / \mathrm{dL}$ ) terjadi setelah responden melakukan konseling gizi dengan cara mengubah pola makan dan berhenti mengonsumsi suplemen protein (Gambar $\mathbf{3}$ dan Gambar 5).

Berdasarkan hasil uji statistik (Paired $t$ Test), status gizi pasien berdasarkan kadar hemoglobin, ureum, dan kreatinin yang melakukan hemodialisis di RSUD Ungaran mengalami perubahan signifikan setelah melaksanakan konseling gizi (Tabel 2). Meskipun perubahan tersebut secara umum tidak dapat dimasukkan ke dalam kategori normal, namun menjadi sebuah indikasi bahwa pasien menjalankan anjuran diet berdasarkan konseling gizi yang telah dilakukan (Tabel 4) dengan memilih jenis makanan dan mengurangi makanan yang tidak dianjurkan khusus bagi penderita gagal ginjal kronik yang melakukan terapi hemodialisa.

Jenis makanan yang dikonsumsi oleh pasien hemodialisa di RSUD Ungaran setelah dilaksanakan konseling gizi selama 2 minggu sudah memiliki perubahan. Makanan yang dikonsumsi telah sesuai diet yang diberikan dari rumah sakit yaitu pasien lebih banyak mengonsumsi makanan sumber protein hewani, seperti ikan lele, telur, daging ayam, dan daging sapi.

Sebelum dilakukan konseling gizi, pasien cenderung mengonsumsi makanan protein nabati berupa tahu dan tempe secara rutin. Setelah diberikan konseling gizi, pasien memang tetap mengonsumsi protein nabati tersebut hanya tidak bersamaan, artinya memilih salah satu dari jenis tahu atau tempe dan cenderung meningkatkan pilihan asupan protein hewani dari jenis daging ayam. Secara keseluruhan, setelah melakukan 
konseling gizi pasien beralih mengonsumsi sumber protein hewani yang memiliki mutu protein lebih tinggi.

Beberapa pasien mengaku bosan mengonsumsi telur secara terus-menerus, lalu beralih untuk mengonsumsi daging ayam. Namun, ada pula pasien yang tidak tahu bahwa pasien diperbolehkan untuk dapat mengonsumsi dagingdagingan, sehingga jenis protein hewani yang dikonsumsinya selama ini hanya terbatas pada telur ayam saja. Ada pula pasien yang sebelumnya mengonsumsi daging sapi dan ikan lele beralih mengonsumsi daging ayam dengan alasan bahwa harga daging ayam lebih murah daripada daging sapi. Pasien yang merasakan mual dan muntah setelah menjalani proses hemodialisis mengubah pilihan makanan dari ikan lele ke daging ayam dengan alasan menghindari bau amis dari ikan yang dapat memicu rasa mual maupun muntah.

Selera makan pasien gagal ginjal kronis mungkin saja dapat menurun sehingga diperlukan berbagai upaya untuk mempertahankan nilai kalori pada diet yang diberikan. Kalori pada pasien hemodialisis harus tercukupi, apabila kalori tidak tercukupi maka dapat menyebabkan kondisi pasien hemodialisis menjadi lemah dan berat badan turun. Untuk menjamin masukan kalori yang cukup, biasanya diberikan tambahan asupan glukosa dan lemak (minyak dan margarin) yang merupakan sumber energi. Santan juga merupakan sumber kalori, tetapi karena santan mengandung kadar kalium yang tinggi, maka pasien lebih memilih memasak dengan menggunakan minyak goreng. Setelah diberikan konseling gizi hemodialisis, pasien yang mengalami gagal ginjal dengan latar belakang hipertensi yang cenderung menyukai pilihan sumber lemak berupa margarin yang memiliki kandungan natrium dan cita rasa asin, kemudian beralih menggunakan minyak goreng. Pengalihan penggunaan margarin ke minyak goreng bertujuan agar tekanan darah pasien tidak bertambah tinggi dan mencegah terjadinya edema.

Tujuan utama pelaksanaan diet bagi pasien hemodialisa melalui pelaksanaan konseling gizi adalah dapat mencapai dan mempertahankan status gizi optimal dengan mempertimbangkan sisa fungsi ginjal agar tidak memperberat kerja ginjal. Selain itu, diet tersebut juga dapat mencegah peningkatan atau menurunkan kadar ureum darah yang tinggi serta dapat mengatur keseimbangan cairan dan elektrolit (21).

Konseling gizi hemodialisa yang dilakukan oleh pasien gagal ginjal kronik berhubungan dengan pengetahuan pasien tentang diet makanan yang dianjurkan dan dilarang untuk dikonsumsi serta penentuan takaran konsumsi makanan dan cairan. Diet merupakan salah satu faktor yang sangat penting dalam penatalaksanaan pasien gagal ginjal kronik yang menjalani hemodialisa. Beberapa sumber diet yang dianjurkan antara lain karbohidrat, protein, lemak, kalsium, vitamin, mineral, dan cairan (21).

Hal utama yang perlu diperhatikan oleh pasien hemodialisa agar kebutuhan zat gizi harian dapat dipenuhi adalah dengan memperhatikan kecukupan asupan makanan dan minuman yang dikonsumsi. Guna mempertahankan keseimbangan nitrogen dan mengganti asam amino yang hilang selama proses hemodialisis, pasien perlu mendapatkan asupan protein tinggi sebesar $1-1,2 \mathrm{gr} / \mathrm{kg}$ BB ideal $/$ hari. Untuk kebutuhan karbohidrat dan lemak, masingmasing berjumlah $55-75 \%$ dan $15-30 \%$ dari kebutuhan energi total (energi cukup diperoleh dari $35 \mathrm{kkal} / \mathrm{kg} \mathrm{BB}$ ideal/hari) (21).

Pemahaman tentang hemodialisa oleh pasien yang mengalami gagal ginjal kronik sangat diperlukan karena ketika pasien paham akan terapi yang mereka lakukan, secara sadar mereka juga akan bertindak disiplin dalam menjalankan hemodialisa. Terapi hemodialisa harus dijalankan secara teratur agar dapat mempertahankan fungsi ginjal yang stabil sehingga tidak mengalami kondisi penyakit yang semakin parah. Selain itu, pengaturan cairan, obat-obatan, aktivitas fisik, dan perubahan gaya hidup seperti diet merupakan penatalaksanaan yang harus dipatuhi oleh pasien gagal ginjal kronis. Pengaturan diet pasien gagal ginjal erat kaitannya dengan konseling gizi karena ketika pasien paham bahwa harus melakukan hemodialisis secara teratur, pasien juga akan berusaha mencari informasi terkait pengaturan diet bagi penyakit gagal ginjal kronik dengan hemodialisa melalui konseling gizi. 
Penentu keberhasilan konseling gizi yang dilakukan oleh pasien hemodialisa adalah pasien itu sendiri. Apabila pasien hemodialisa melakukan hal yang disarankan oleh ahli gizi terkait larangan dan anjuran makan serta pembatasan cairan yang dikonsumsi, keluhan seperti sesak nafas serta nilai biokimia darah, meliputi hemoglobin, ureum, dan kretainin juga akan mengalami perubahan. Pasien gagal ginjal kronik pada awal menjalani hemodialisa mengikuti anjuran batasan asupan nutrisi dan cairan yang diberikan oleh konselor, sehingga tidak ditemukan adanya keluhan (21). Namun, seiring berjalannya waktu, pola makan pasien mengalami perubahan yakni tidak mengonsumsi makanan dan cairan yang dianjurkan maupun yang dilarang (pantangan), sehingga pada terapi hemodialisa berikutnya masih sering terjadi pasien datang dengan keluhan misalnya sesak nafas akibat konsumsi makanan bersantan atau mengalami edema akibat konsumsi garam berlebih terutama pada pasien dengan komplikasi hipertensi.

\section{KESIMPULAN DAN SARAN}

Pelaksanaan konseling gizi yang diikuti oleh pasien hemodialisa di RSUD Ungaran, Jawa Tengah memberikan hasil positif yang signifikan terhadap perubahan status gizi pasien berupa peningkatan kadar hemoglobin serta penurunan kadar ureum dan kadar kreatinin. Meskipun terjadi perubahan, angka perubahan tersebut tidak berada pada batas normal yang ditetapkan. Namun, kondisi tersebut mengindikasikan bahwa upaya konseling gizi yang diberikan memberikan manfaat positif bagi pasien untuk mendapatkan pengetahuan tentang pengaturan pola makan, termasuk pemilihan jenis makanan yang tepat, takaran, penyusunan menu harian, pembatasan konsumsi jenis makanan tertentu; serta melaksanakan anjuran diet yang telah disampaikan oleh konselor gizi guna mengoptimalkan fungsi kerja ginjal agar tidak bekerja secara berlebihan.

Perlu dilakukan penelitian lanjutan terkait kepatuhan pasien hemodialisa yang mengikuti konseling gizi dengan durasi pengamatan atau penelitian lebih panjang. Berdasarkan kepatuhan pasien tersebut dapat dilakukan evaluasi terhadap perilaku pasien terkait pelaksanan anjuran yang diberikan oleh konselor gizi, didukung data sekunder dari hasil pemeriksaan laboratorium terhadap perubahan kadar hemoglobin, ureum, dan kreatinin pasien.

Bagi pasien atau keluarga pasien, disarankan untuk tetap secara rutin mengikuti konseling gizi dan menjalankan diet berdasarkan anjuran yang diberikan oleh konselor gizi guna mencapai dan mempertahankan status gizi optimal agar tidak memberatkan kerja ginjal. Selain itu, dapat pula dibentuk komunitas khusus bagi penderita gagal ginjal kronik dengan hemodialisa sebagai wadah untuk menampung dan membagikan informasi seputar gaya hidup dan diet yang tepat serta saling memberikan dukungan agar penderita yang belum memahami tentang pengaturan pola makan atau bahkan belum pernah mengikuti konseling gizi dapat secara rutin mengikuti kegiatan konseling tersebut.

\section{UCAPAN TERIMA KASIH}

Penulis menyampaikan ungkapan terimakasih kepada Unit Hemodialisa dan Instalasi Gizi RSUD Ungaran yang telah memberikan kesempatan serta memfasilitasi pelaksanaan penelitian hingga akhir.

\section{RUJUKAN}

1. Davids MR. Chronic kidney disease - the silent epidemic. Chronic kidney disease brings a huge burden of premature death. Contin Med Educ. 2007;25(8):378.

2. Snyder JJ, Foley RN, Collins AJ. Prevalence of CKD in the United States: a sensitivity analysis using the National Health and Nutrition Examination Survey (NHANES) 1999-2004. Am J Kidney Dis. 2009;53(2):218-28.

3. Firmansyah MA. Usaha memperlambat perburukan penyakit ginjal kronik ke penyakit ginjal stadium akhir. Cermin Dunia Kedokt. 2010;37(3):181-5.

4. Badan Penelitian dan Pengembangan Kesehatan Departemen Kesehatan. Laporan nasional riset 
kesehatan dasar (RISKESDAS) tahun 2010. Jakarta; 2010.

5. K S. Buku ajar ilmu penyakit dalam, jilid II edisi V. Jakarta: FKUI; 2010.

6. Muttaqin A, Sari K. Asuhan keperawatan gangguan perkemihan. Jakarta: Salemba Medika; 2011.

7. Locatelli F, Fouque D, Heimburger O, Drüeke TB, Cannata-Andía JB, Hörl WH, et al. Nutritional status in dialysis patients: a European consensus. Nephrol Dial Transplant. 2002;17(4):563-72.

8. Denhaerynck K, Manhaeve D, Dobbels F, Garzoni D, Nolte C, De Geest S. Prevalence and consequences of nonadherence to hemodialysis regimens. Am J Crit Care [Internet]. American Association of Critical Care Nurses; 2007 [cited 2016 Dec 1];16(3):222-35. Available from: http://m.ajcc.aacnjournals.org/cgi/ reprintframed/16/3/222/

9. Supariasa, Bachyar B, Ibnu F. Penilaian status gizi. Jakarta: EGC Buku Kedokteran; 2001. 17$54 \mathrm{p}$.

10. Ma 'shumah N, Bintanah S, Handarsari E, Studi P, Fakultas G, Keperawatan I, et al. Hubungan asupan protein dengan kadar ureum, kreatinin, dan kadar hemoglobin darah pada penderita gagal ginjal kronik hemodialisa rawat jalan di RS Tugurejo, Semarang. J Gizi Univ Muhammadiyah Semarang. 2014;3(1):22-32.

11. Anggraeni AC. Asuhan gizi nutritional care process. Yogyakarta: Graha IImu; 2012.

12. Hidayat $T$, Istiadah N. Panduan lengkap menguasai SPSS 19 untuk mengolah data statistika penelitian. Yogyakarta: PT TransMedia; 2011.

13. Parsudi A. Ginjal dan hipertensi pada usia lanjut dalam geriatri ilmu kesehatan usia lanjut. Edisi 4. Jakarta: Penerbit FK-UI; 2009.

14. Sutedjo AY. Buku saku mengenal penyakit melalui hasil pemeriksaan laboratorium. Yogyakarta: Penerbit Amara Books; 2009.

15. Benez. Klasifikasi stadium gagal ginjal kronik pada pria yang menderita gagal ginjal kronik berdasarkan perhitungan laju filtrasi glomerulus di RSMH Palembang periode 1 Januari 2003 31 Desember 2004 [Internet]. 2006. Available from: http://faw.jurnalpenelitian.com.unair/jurnal/ publication/index/20benez.htm

16. Smeltzer S., Bare B. Buku ajar keperawanan medial bedah, Edisi 3, Volume 2. Jakarta: EGC Buku Kedokteran; 2002.

17. Noer MS. Gagal ginjal kronik pada anak [Internet]. 2006 [cited 2017 Mar 29]. Available from: https:// d2ncoem.files.wordpress.com/2010/09/ginjal. pdf

18. Alam S, Hadibroto I. Gagal Ginjal. Yogyakarta: Pt Gramedia Pustaka Utama; 2007.

19. Guyton $\mathrm{H}$. Buku ajar fisiologi kedokteran. Edisi 9. Jakarta: EGC; 1997. 521 p.

20. Kugler C, Vlaminck $H$, Haverich A, Maes B. Nonadherence with diet and fluid restrictions among adults having hemodialysis. J Nurs Scholarsh an Off Publ Sigma Theta Tau Int Honor Soc Nurs. 2005;37(1):25-9.

21. Hudak, Gallo. Keperawatan kritis pendekatan holistik edisi VI. Jakarta: EGC; 2006. 